Mischa Suter, Department of History, University of Basel

mischa.suter@unibas.ch

\title{
Debt and Its Attachments: Collateral as an Object of Knowledge in
}

\section{Nineteenth-Century Liberalism}

Note to readers: this is the penultimate manuscript version of the essay. For reference, please consult the published version: Suter, Mischa: "Debt and Its Attachments: Collateral as an Object of Knowledge in Nineteenth-Century Liberalism", in: Comparative Studies in Society and History 59 (2017) Nr. 3, S. 715-742.

\begin{abstract}
This essay partakes in the dialogue between history, anthropology, and social theory on the topic of debt as a social relation. Drawing on sources from nineteenthcentury Switzerland, it examines everyday routines of debt collection in liberalism by taking the seized collateral object to the center of historical analysis. It is shown how the attached goods in a debtor's household became an object of knowledge for nineteenthcentury framers of law as well as for ordinary debtors. I make use of anthropological theory in order to describe the legal techniques of delineating and extracting collateral, and I show how these legal techniques implied specific knowledge practices. I then look at two borderline cases of collateralization: the pawning of mobile goods and the imprisonment of insolvent debtors. Further I discuss how, by the 1880s, the limits of debt collection were discussed, when certain goods were exempt for seizure in a projected federal law. Overall, on an epistemological level, debt collection appears as a double movement: it provided basic tools to untangle property relationships, yet all the while it created new, unpredictable complications. Thus debt collection was a distinctive arena in which the uneasy conceptual relationship between people and things in nineteenthcentury liberalism unfolded. From this conceptual node I propose a historical epistemology of the collateral object.
\end{abstract}


In truth societies are not simply problem-solving mechanisms: they are also problem-

creating mechanisms.

Marilyn Strathern, The Gender of the Gift, 33.

\section{An Introduction to the Problem}

This essay deals with reflections about the objectification of relationships and the volatility of things in nineteenth-century liberalism by looking at the routine collection of debts. In particular, I examine the methods of collateralization and focus on the role of movable collateral in the relationship between borrowers and lenders. This approach highlights an otherwise inconspicuous object within the debt relationship, that is, the collateral itself. Shifting the collateral object into the center of historical analysis, offers new perspectives on the history of debt and, more generally, additional insight into the complicated relationship between personhood and things in nineteenth-century everyday life. For the object meant to provide a guarantee - the good that is used as collateral — in its materiality encapsulates social relations. The characteristics of collateralization become urgent in cases of debt collection in which objects are legally seized. This essay thus appraises the seizure of property in debt enforcement in the context of other forms of collateralization like the pawning of objects. I turn to anthropological theory to better understand the ways in which collateral objects were assessed, fenced in, and transferred - in other words, how this unremarkable thing became an object of knowledge. Thus I venture the argument that the methods of collateralization provided a basic legal technique that stabilized the relationality of debt in nineteenth-century liberalism, yet by the same token these methods introduced new irreconcilable irritations. The approach proposed here provides new insights into the culture of borrowing and 
lending and ultimately, into the everyday workings of liberalism. ${ }^{1}$ I will map out my understanding of liberalism as the argument unfolds, but for the moment, let me propose an initial definition of liberalism as a "rule at a distance" intended to create selfregulating circuits of goods, people, and information. ${ }^{2}$ Liberalism was further, and essentially, linked to the rule of law, to principles of due process, and to a distinct valorization of private property. And liberalism was, finally, acutely preoccupied with the relation between subject and object, between personhood and things. In Switzerland - a country that was viewed as a laboratory of economic and political liberalism and the case study that provides the sources for this essay - liberalism's legal techniques of debt collection were based on customary routines; a law of practices, so to speak. ${ }^{3}$

Focusing on collateralization, it is possible to provide specific historical answers to broad questions: it helps to better understand the inner life of nineteenth-century liberalism by examining the everyday efforts of historical actors to mobilize things, to keep the categories of "things" and "persons" separated, and to tirelessly fabricate a circumscribed realm for things as things. Law played a constitutive role in "dividing up inchoate substance into discernible chunks of stuff," as has recently been argued in a suggestive article on the materiality of law. In what follows, I examine these mundane

\footnotetext{
${ }^{1}$ This is in part a response to the call for historical research based on the "unpaid" (l'impayé). Compare Claire Lemercier and Claire Zalc, "Pour une nouvelle approche de la relation de crédit en histoire contemporaine," Annales: Histoire, sciences sociales 67, no. 4 (Oct.-Dec. 2012): 979-1009.

2 Joyce, The Rule of Freedom: Liberalism and the Modern City (London, 2003), 100.

${ }^{3}$ On the political culture of liberalism in nineteenth-century Switzerland, compare: Lerner, Laboratory of Liberty; Elisabeth Joris, Liberal und eigensinnig. Die Pädagogin Josephine Stadlin - die Homöopathin Emilie Paravicini-Blumer (Zurich, 2010); Oliver Zimmer, A Contested Nation: History, Memory, and Nationalism in Switzerland, 1761-1891 (Cambridge, 2003); Barbara Weinmann, Eine andere Bürgergesellschaft. Klassischer Republikanismus und Kommunalismus im Kanton Zurich im späten 18. und 19. Jahrhundert (Göttingen, 2002); and Gordon A. Craig, The Triumph of Liberalism: Zürich in the Golden Age, 1830-1869 (New York, 1988).
} 
legal techniques with an eye on knowledge practices. ${ }^{4}$ The goal is to better understand how the experience of things shaped new concepts; or, in other words, to examine how thought occurred via things. ${ }^{5}$ Thus my argument expands on long-held interests in the historiography of lending and borrowing with its keen sense for material culture. ${ }^{6}$ For, as has been observed for early modern times and for the nineteenth century alike, the perceived creditworthiness of a person was a "fluctuating identity", linked to personal appearance and demeanor in which immaterial and material dimensions overlapped. ${ }^{7}$ In credit dealings, objects were constantly an indicator of social significance and thus provided a point of orientation for the historical actors. ${ }^{8}$ The social fabric of credit had tangible aspects. Yet the three-way relationship between objects, their monetary value, and the personhood of the debtor was repeatedly contested. The use of goods as collateral thus illustrates the persistently difficult relationship between personhood and mobile

\footnotetext{
${ }^{4}$ Tom Johnson, "Medieval Law and Materiality: Shipwrecks, Finders, and Property on the Suffolk Coast, ca. 1380-1410," American Historical Review 120, no. 2 (April 2015): 408 (quote). For approaches consonant with the following argument, see Alan Pottage, Martha Mundy, eds., Law, Anthropology and the Constitution of the Social: Making Persons and Things (Cambridge, 2004) and Timothy Mitchell, Rule of Experts: Egypt, Techno-Politics, Modernity (Berkeley, 2002).

${ }^{5}$ Amira Henare, Martin Holbraad, and Sari Wastell, "Introduction," in Thinking through Things: Theorising Artefacts Ethnographically (London, 2007), 1-31: esp. 12-16. On such anthropologically informed perspectives in historical scholarship, see Delphine Gardey, Le linge du Palais-Bourbon: Corps, matérialité et genre du politique à l'ère démocratique (Lormont, 2015) and Jakob Tanner, Historische Anthropologie zur Einführung (Hamburg, 2004), chap. 6. In a different register, Rebecca Spang's study impressively links multiple dimensions of money, both as a sign system and as material stuff. See her Stuff and Money in the Time of the French Revolution (Cambridge, MA, 2015).

${ }^{6}$ The most obvious area for this interest in material culture is the history of consumer credit. See, Jan Logemann, ed., The Development of Consumer Credit in Global Perspective: Business, Regulation, and Culture (New York, 2012); Sean O'Connell, Credit and Community: Working-Class Debt in the UK since 1880 (Oxford, 2009); Beverly Lemire, The Business of Everyday Life: Gender, Practice and Social Politics in England, c. 1600-1900, (Manchester, 2005); Erika Rappaport, “ 'A Husband and His Wife's Dresses': Consumer Credit and the Debtor Family in England, 1864-1914", in Victoria De Grazia, ed., The Sex of Things: Gender and Consumption in Historical Perspective (Berkeley, CA, 1996), 163-187; James Carrier, Gifts and Commodities: Exchange and Western Capitalism since 1700 (London, 1995).

${ }^{7}$ Margot Finn, The Character of Credit: Personal Debt in English Culture, 1740-1914 (Cambridge, 2003), quote on 21; Clare Haru Crowston, Credit, Fashion, Sex: Economies of Regard in Old Regime France (Durham, NC, 2013), 98.

${ }^{8}$ Laurence Fontaine, The Moral Economy: Poverty, Credit and Trust in Early Modern Europe (Cambridge, 2014); Muldrew, The Economy of Obligation: the Culture of Credit and Social Relation in Early Modern England (Basingstoke, 1998).
} 
objects. With respect to the history of nineteenth-century liberalism, this is an argument that stresses both continuities and specificity. For a uneasiness with the ability to move and fix objects can be traced to much earlier epochs and remains urgent for debt dealings in present-day capitalism. ${ }^{9}$ For example, medievalist Martha Howell points to the legal techniques in late-medieval commerce that drew a distinction between mobile and immobile goods and allowed for specific types of mobilization of each. ${ }^{10}$ Conversely, anthropologist Janet Roitman observes on foreclosed houses in the United States after 2008 that no a priori value lying in a material object (a home) was being translated into house prices, but rather the reverse: processes of valuation lead to the expulsion of inhabitants and affected the materiality of the objects, turning houses into ruins. ${ }^{11}$

And yet the story of nineteenth-century debt law also gives indication for historical specificity and changes when legal experts as well as ordinary creditors and debtors negotiated the status of human bodies, pocket watches, religious icons, or dung piles as collateral. Liberal nineteenth-century legal principles fostered a material conception of property that equated ownership with the total and perfect sovereignty over an object. ${ }^{12}$ And if the subject was formed by the possession of objects, as presupposed in

\footnotetext{
${ }^{9}$ I would like to thank an anonymous commentator on an earlier version of the essay who encouraged me to stress this crucial point more clearly.

${ }^{10}$ Martha Howell, Commerce before Capitalism in Europe, 1300-1600, (Cambridge, 2010), chap. 1.

${ }^{11}$ Janet Roitman, Anti-Crisis (Durham, NC, 2014), esp. 47-56, 77. See also Ute Tellmann, "Schuldeneine Kultursoziologie ökonomischer Dinge", in Joachim Fischer, ed., Kultursoziologie im 21. Jahrhundert (Wiesbaden, 2014), 159-170.

12 Dieter Schwab, "Eigentum," in Otto Brunner, Werner Conze, Reinhart Koselleck, eds., Geschichtliche Grundbegriffe. Historisches Lexikon zur politisch-sozialen Sprache in Deutschland, vol. 2 (Stuttgart, 1975), 78; Robert Descimon, "Reading Tocqueville: Property and Aristocracy in Modern France," in Robert Schneider, Robert M. Schwartz, eds., Tocqueville and Beyond: Essays on the Old Regime in Honor of David D. Bien (Newark, NJ, 2003), 111-126; Mikhail Xifaras, La propriété. Etude de philosophie du droit (Paris, 2004).
} 
the legal and cultural expectations of liberalism, persons and their things were intertwined, and the seizure of goods touched upon a sensible link. ${ }^{13}$

I try to substantiate this argument in four steps. I first provide some context on the Swiss system of debt collection and on my approach to the question at hand. Then I outline how legal techniques of collateralization, despite their seeming simplicity, hid fundamental contradictions. Since such contradictions become especially apparent in borderline cases of collateralization, section three examines two such cases that were common, yet albeit precarious in the nineteenth century: the imprisonment of debtors, where the body served as collateral, and the pawning of goods. The discussion finally leads to certain limits on collateralization, limits that exempted some household goods from seizure - such limits, which were intended to protect the debtor, were discussed in relation to the federal law of 1892 in a moment when the subsistence level was an issue of widespread social debate. In the conclusion, I propose a historical epistemology of the collateral object by linking the changing ways of collateralization to different ways of knowing: compartementalized, investigative, liminal, or taxonomical forms of knowledge.

\section{Situating Collateral}

To delve into the specificities of collateral, nineteenth-century Switzerland is an apt case. In this early industrialized society debt collection remained based on received practices, until the latter were standardized in a federal law, the "federal statute on debt enforcement and bankruptcy" that was passed in 1889 and went into effect in 1892 . There was much continuity between early modern systems and liberalism's rule of law: the

\footnotetext{
${ }^{13}$ Margaret Jane Radin, Reinterpreting Property (Chicago, 1993), 35-71.
} 
collection of debts relied on accessible, quotidian ways of legal procedure whose administrative barriers (the costs and efforts it required of creditors and debtors alike), however, were successively lowered throughout the nineteenth century. By century's end, the federal law of 1892 established a fundamental difference between bankruptcy proceedings - which involved inventorying a debtor's entire property and redistributing it among his creditors according to a fixed allocation formula — and attachment—in which property of the debtor was seized for each individual claim. ${ }^{14}$ Prior to the introduction of this federal law, many variations and combinations of these basic models of debt collection existed, and objects could be attached to force payment in a variety of ways. ${ }^{15}$ Debt collection also touched upon the status of citizenship, which itself in turn underwent changes in the nineteenth century, for the bankruptcy of a male debtor resulted in the loss of his civil rights. This stripping on one's honor was of great concern within a republican political system which — compared to the other European states—was based on an unprecedented level of male suffrage.${ }^{16}$ While the social effects and cultural significance of bankruptcy proceedings have garnered significant attention from historians, I address the less conspicuous moment in which property was legally seized. ${ }^{17}$ After all, a

\footnotetext{
${ }^{14}$ See Yves Le Roy, "Le choix des voies de poursuite à la fin du XIXe siècle, en particulier dans le projet de loi fédérale sur la poursuite pour dettes et la faillite du 23 février 1886," in Le Droit commercial dans la société suisse du XIXe siècle, ed. Pio Caroni, (Fribourg, 1997), 250-303.

${ }^{15}$ The broad spectrum of methods of debt collection in Switzerland was met with great amazement ("étonnement") by the Frenchman Edmond Thaller in his comparison of international bankruptcy laws: Des faillites en droit comparé, avec une étude sur le règlement des faillites en droit international, vol. 1 (Paris, 1887), 97.

${ }^{16}$ Zimmer, Contested Nation, 122, esp. Fn. 13; however, on the limits of franchise see Albert Tanner, "Ein Staat nur für die Hablichen? Demokratie und politische Elite im frühen Bundesstaat", in Brigitte Studer, ed., Etappen des Bundesstaates. Staats- und Nationsbildung der Schweiz, 1848-1998 (Zurich, 1998), 6388 .

${ }^{17}$ See, among others, Dorothee Guggenheimer, Kredite, Krisen und Konkurse. Wirtschaftliches Scheitern in der Stadt St. Gallen im 17. und 18. Jahrhundert (Zurich, 2014); Thomas Max Safley, ed., The History of Bankruptcy: Economic, Social and Cultural Implications in Early Modern Europe (New York, 2013); Ingo Köhler and Roman Rossfeld, eds., Pleitiers und Bankrotteure. Zur Geschichte wirtschaftlichen Scheiterns, (Frankfurt, 2012); Erika Vause, “"He Who Rushes to Riches Will Not Be Innocent': Commercial Values
} 
contemporary expert estimated that 75 to 80 percent of all cases of debt collection in Switzerland involved the seizure of collateral objects, handled by low-level officials, rather than bankruptcy proceedings (they had, however, the same effect on the debtor's civil rights if he was completely stripped of all his assets). ${ }^{18}$ These seizures were inconspicuous and simple: the value of the seized goods was only roughly estimated because the latter were only temporarily attached (in most cases, the debtor paid before the goods were liquidated), and, in case of liquidation, in most instances were subject to an auction. It is therefore important to emphasize the limited administrative costs of the legal system of debt collection in Switzerland in the nineteenth century. Attachment involved little state intervention: a system of deadlines and sanctions governed these administrative routines of summary justice almost independently, and judicial hearings were rarely necessary. ${ }^{19}$ Legal experts were certain that the various laws of debt enforcement had "grown on the soil of habit.",20 Debt collection by attachment was based on stable procedures since early modern times in which republican, communal forms of governance were imbricated with newly emerging forms of state expertise. In the course and Commercial Failure in Postrevolutionary France," French Historical Studies 35, no. 2 (Spring 2012): 321-349; Julie Hardwick, "Banqueroute : la faillite, le crime et la transition vers le capitalisme dans la France moderne", in Histoire, Economie \& Société 30, no. 2 (2011): 79-93; Scott Sandage, Born Losers. A History of Failure in America (Cambridge, Mass., 2005); Edward J. Balleisen, Navigating Failure. Bankruptcy and Commercial Society in Antebellum America (Chapel Hill, N.C., 2001); Robert Beachy, "Bankruptcy and Social Death: The Influence of Credit-Based Commerce on Cultural and Political Values," in Zeitsprünge. Forschungen zur Frühen Neuzeit 4, no. 4 (2000): 329-343; Toby L. Ditz, "Shipwrecked; or Masculinity Imperiled: Mercantile Representations of Failure and the Gendered Self in Eighteenth-Century Philadelphia," Journal of American History 81, no. 1 (June 1994): 51-80.

${ }^{18}$ Schweizerisches Bundesarchiv (hereafter BAR) E 22 1000/134 2609, Johann Jakob Oberer to Federal Counselor Louis Ruchonnet, Liestal, June 2 1882. Oberer based his estimation on statistics for the cantons of Zurich, Schaffhausen, and Baselland.

${ }^{19}$ German legal scholars reported with admiration of this system which was organized to be much more "energetic and better for the common good" than that in Germany. Quote from Fr. Wyß,

"Schuldbetreibung," in Johann Caspar Bluntschli, ed., Deutsches Staats-Wörterbuch, vol. 9 (Stuttgart/Leipzig 1865): 258-264, 264.

${ }^{20}$ Alexander Reichel, "Referat: Das Betreibungsamt im schweizerischen Recht," Zeitschrift für schweizerisches Recht 28 (1887): 567-607; Zur Volksabstimmung vom 17. November 1889. Ein Wort der Aufklärung an das Schweizervolk zum Bundesgesetze über Schuldbetreibung und Konkurs (Bern, 1889), 6. 
of the nineteenth century, new supervising bodies assumed authority over these entrenched legal routines. The principles of due process and transparency of the state were tied to decentralized power and localized oversight. The systematization of received forms of procedure gave the ways of debt enforcement characteristics we might term "liberal". Distant, mediated forms of power became more widespread, for instance, when during the first half of the century, insolvent debtors were less and less publicly proclaimed in Sunday church but rather by way of the newly installed official gazette. ${ }^{21}$ With the reordering of government in many Swiss cantons by the 1830s procedures of debt collection were further systematized and made more accessible: deadlines were successively shortened, procedural fees were lowered, oversight of local level officials was tightened, bankruptcy statistics were made public. Above all, this system in the interest of the preservation of private property and credit was centered on objects. Delineating and transferring things in order to guarantee a creditor's claim was done by way of compartementalized knowledge: instead of protracted negotiations, a thing simply stood in for the owed sum. The advantages were not lost on contemporary experts. For example, a German handbook on economic and legal government recommended the Swiss system of debt collection, noting that it was "much more rigorously and beneficially arranged" than its counterparts in most German lands. ${ }^{22}$ Liberalism for sure is a multifaceted, contested term, yet in the context of the economic and legal routines with which this essay deals, the aspects that inform my use of the term

\footnotetext{
${ }^{21}$ I discuss this shift in more detail in Mischa Suter, "The Boundaries of Debt: Bankruptcy between Local Practices and Liberal Rule in Nienteenth-Century Switzerland", in Chia Yin Hsu, Thomas Luckett, Erika Vause (eds.), The Cultural History of Money and Credit: A Global Perspective (Lanham, MD 2016), 5455.

${ }^{22}$ Friedrich von Wyß, "Schuldbetreibung", in, Johann Caspar Bluntschli (ed.): Deutsches Staats-

Wörterbuch, vol. 9 (Stuttgart/Leipzig, 1865), 264, n.
} 
converge in their relationship to materiality. The political effects of objects' arrangements thus present one possibility for a study of the practical workings of liberalism. Liberalism mobilized materials, as historians have shown with regards to urban surroundings: asphalt floors, glass display windows, systems of pipes, and postal routes facilitated solidity, transparency, smoothness, and efficiency. ${ }^{23}$ Under liberalism, authority was conveyed in large part via objects, but the very "thingness" of these objects repeatedly limited and thwarted liberal governance. ${ }^{24}$ Burst pipes, broken glass windows, brittle concrete, and lost mailings testified to the contingency of the concrete world. The structure of power in liberalism was facilitated by the definition, measure, appraisal, and transferal of objects. In the process of completing these everyday transactions, new imponderabilities constantly emerged. Thus examining which techniques were employed to seize, limit, and transfer property in such cases reveals a profound ambiguity within the social life of property in the nineteenth century, for in collateralization the fundamental relationality of debts became locked up in an object. ${ }^{25}$ On the one hand, collateralization, as it had been handled since early modern times, substantially simplified the process of debt collection. On the other hand, collateralization created unsolvable problems that demonstrate a blind spot in liberalism's regime of truth.

\footnotetext{
${ }^{23}$ Patrick Joyce, The State of Freedom: A Social History of the British State since 1800 (Cambridge, 2013); Chris Otter, The Victorian Eye: A Political History of Light and Vision in Britain, 1800-1910 (Chicago, 2008); Chris Otter, "Making Liberalism Durable: Vision and Civility in the Late Victorian City," Social History 27 (January 2002): 1-15.

${ }^{24}$ On the disruptive "thingness" of objects see Bill Brown, "Thing Theory", Critical Inquiry 28, no. 1 (Autumn, 2001), quote on 4; Trentmann, Frank: "Materiality in the Future of History: Things, Practices, and Politics," in Journal of British Studies 48, no. 2 (2009): 283-307.

${ }^{25}$ On the ambiguity of property in the nineteenth century see Jonathan Sperber, Property and Civil Society in South-Western Germany 1820-1914 (Oxford, 2005); Georg Fertig, Äcker, Wirte, Gaben. Ländlicher Bodenmarkt und liberale Eigentumsordnung im Westfalen des 19. Jahrhunderts (Berlin, 2007); Rebekka Habermas, Thieves in Court: The Making of the German Legal System in the Nineteenth-Century (Cambridge, forthcoming).
} 
In order to dissect such blind spots certain research strands between history, anthropology, and science studies "symmetrize" the relationship between people and things by regarding material and symbolic dimensions in one analytical frame. Among historians such a program is most commonly associated with Bruno Latour's plea for an "intrinsic logic" or "agency of things, ${ }^{, 26}$ but in this case it is the anthropologists Marilyn Strathern and Annelise Riles who have provided the theoretical impulse. ${ }^{27}$ Personhood and things, according to Strathern and Riles, are mutually interdependent, they do not exist beyond their relation, but are created by the interactions of contrasting perspectives. This opens new possibilities for examining knowledge practices; for example, processes of estimation and worth measurement via which historical actors shaped economic variables like "value" or "commodity" by classifying certain things as "economic." ${ }^{28}$ In the relationship between creditor and debtor, the collateral stands in as what Riles terms a "placeholder." Collateral as a placeholder is a device that mediates a credit relationship. It temporarily stands in for the duration of the unmet debt. As an object, it brings the instability of the debt relationship to a halt. Viewed in temporal terms, the placeholder is an object of suspension. Collateral works as if the transaction had already taken place; "it

\footnotetext{
${ }^{26}$ To use the phrase coined by Bert de Munck. Bert de Munck, "Artisans, Products and Gifts: Rethinking the History of Material Culture in Early Modern Europe," Past and Present 224 (August 2014): 39-74.

${ }^{27}$ Bruno Latour, We Have Never Been Modern, transl. Catherine Porter (Cambridge, MA, 1994); Marilyn Strathern, The Gender of the Gift: Problems with Women and Problems with Society in Melanesia (Berkeley, 1988); Marilyn Strathern, Property, Substance, and Effect: Anthropological Essays on Persons and Things (London, 1999); Annelise Riles, Collateral Knowledge: Legal Reasoning in the Global Financial Markets, (Chicago, 2011). For an overview of Strathern's impact on debates in social theory, see Alice Street, Jacob Copeman, eds., "Social Theory after Strathern," special issue Theory, Culture \& Society 31, nos. 2 and 3 (January 2014); Olivier Allard, Guillaume Calafat, Nathalie La Valle, eds., "Traduire et introduire: Calveiro - Smail - Strathern," special issue Tracés: revue des sciences humaines, hors-série 14, no. 3 (2014).

${ }^{28}$ From various perspectives on the practices of classification that qualified specific things as "economic" (not drawing on Strathern or Riles, in particular, however), see Jane Guyer, Marginal Gains. Monetary Transactions in Atlantic Africa, (Chicago, 2004); Daniel Vickers, "Errors Expected: The Culture of Credit in Rural New England, 1750-1800," in Economic History Review 63, no. 4 (2010): 1032-1057; Alexandra Shepard, Accounting for Oneself: Worth, Status and the Social Order in Early Modern England (Oxford, 2015).
} 
forecloses the question of the moment for the near future," Riles writes, "by creating a dummy solution subject to future reevaluation. ${ }^{.29}$ Fairly inconspicuous knowledge practices created the conditions under which this substitution could take place. Here comes into play what I would like to call a historical epistemology of the collateral object. As historian Ann Stoler has shown, historical epistemology has developed a much more "worldly" scholarly usage beyond that of a formal theory of scientific knowledge. ${ }^{30}$ Accordingly, concepts and techniques that bring to the fore certain forms of knowledge have become evident in the most varied of contexts, not just in the scientific laboratory or the scholar's library. "Value" is such a fundamental concept, to which "insolvency" is related. ${ }^{31}$ The process of posting collateral in a debtor-creditor relationship contained moments of appraisal and commensuration in which concrete particularities had to be transformed into interchangeable values. ${ }^{32}$ Different ways of knowing took shape in these procedures, as will be shown in the subsequent sections. Compartementalized, investigative, liminal, or taxonomical modalities of knowledge lent themselves to the different forms of assessing and transferring things in collateralization, as a look at the seizure of objects, the imprisonment of debtors, pawnbroking, and at the limits on seizure that protected a debtor makes clear. At the same time, "epistemological fears"- to adapt the fitting phrase used by Lorraine Daston and Peter Galison_-impinged on the practices

\footnotetext{
${ }^{29}$ Annelise Riles, "Collateral Expertise: Legal Knowledge in the Global Financial Markets", Current Anthropology 51, no. 6 (December 2010): 803.

${ }^{30}$ Ann Laura Stoler, Along the Archival Grain: Epistemic Anxieties and Colonial Common Sense (Princeton, 2009), 42. See also, Mary Poovey, A History of the Modern Fact: Problems of Knowledge in the Sciences of Wealth and Society (Chicago, 1998), 17.

${ }^{31}$ Mary Poovey, Genres of the Credit Economy. Mediating Value in Eighteenth- and Nineteenth-Century Britain (Chicago, 2008).

${ }^{32}$ For a reflection on such processes of transformation in varied historical contexts see: John L. Comaroff and Jean Comaroff, "Currencies of Conversion," chap. 4 in Of Revelation and Revolution, vol. 2, The Dialectics of Modernity on a South African Frontier (Chicago, 1997); Carl Wennerlind, "The Epistemology of Credit," chap. 3 in Casualties of Credit: The English Financial Revolution, 1620-1720, (Cambridge, MA, 2011).
} 
used to determine, value, property, and insolvency. ${ }^{33}$ The seizure of the collateral object was in essence a sequestration of the social relationship in a thing and consequentially a controlling of this "epistemic anxiety." "34 Yet the methods of collateralization themselves simultaneously threatened to undermine the practice of debt enforcement at an epistemic level.

\section{Attaching Property, Fabricating Collateral}

To seize property in order to legally collect debts had something of a fundamental balance of power between two opponents, as contemporaries repeatedly observed. Debtors who hid their property to prevent its seizure competed with creditors who strove to attach the debtors' most precious goods. ${ }^{35}$ In the words of the historian Jonathan Sperber, hiding assets from creditors was a "major nineteenth-century participant and spectator sport." ${ }^{36}$ In this everyday shuffling of property back and forth, seizure of goods was an inconspicuous procedure. Whereas bankruptcy proceedings were often drawn out and required the compilation of a comprehensive inventory of a debtor's property by a certified notary, the records associated with the attachment of a debtor's assets were often rudimentary and compiled by lesser communal bailiffs. As a "placeholder" in the debt relationship, collateral made exact knowledge unnecessary. Instead of a careful evaluation of value, a number of things could simply be attached. These bailiffs did not need to know much. Since the things were only meant to be attached temporarily - and,

\footnotetext{
${ }^{33}$ Lorraine Daston and Peter Galison, Objectivity (New York, 2007), 48; I draw here especially on the usage of the concept in Stoler, Archival Grain.

${ }^{34}$ Stoler, Archival Grain; Daston and Galison, Objectivity, 49.

${ }^{35}$ A collection of such didactic satirical stories is included in Avons-nous payé nos dettes? (Lausanne, 1875), 10f; on creditors' "hunts" for the most valuable pieces of property, see, among others, R. Brunner, Der Gesetzesentwurf über Schuldbetreibung und Konkurs. Vortrag gehalten im bernischen Verein für Handel und Industrie, Montag den 2. Mai 1887 (Berne, n.d.).

${ }^{36}$ Sperber, Property, 120.
} 
in fact, often remained within the household of the debtor unless the creditor demanded their removal — it was not necessary to assign a monetary value to each individual item. ${ }^{37}$ The bailiff only appraised whether or not the total value of the attached goods equaled that of the outstanding debt. A few simple notes in a standardized, preprinted record book were sufficient in such cases. In that sense, collateralization created, as Annelise Riles calls it, "a set of routinized knowledge practices.",38

This basic legal technique, however, which did not generally involve a judge, often encountered practical complications. Attachment worked within the structure of social obligations. Local authorities secretly strove to counter the danger of domino effects that could result from insolvency. In an effort to avoid the costs associated with having to provide for a bankrupt debtor from the communal alms, these local officials chronically drew out the proceedings. When, by the 1830 s, liberal cantonal governments introduced new forms of justice and transparency, countless complaints concerning this neglect came to light. ${ }^{39}$ The local officials proved especially reticent when faced with the final auction of attached property.

Beyond this reticence, however, the sheer materiality of objects created difficulties. As a petition from officials in Zurich shows, the impounding of animals was

\footnotetext{
${ }^{37}$ Auszüge aus den obergerichtlichen Rechenschaftsberichten von den Jahren 1872 bis und mit 1885, hauptsächlich das Notariatswesen und die Gemeindeammänner betreffend, möglichst alphabetisch geordnet. Jedermann als Hülfs- und Nachschlagbuch dienend (Affoltern a.A., 1887), $31 \mathrm{f}$.

${ }_{38}$ Riles, Collateral Knowledge, 21.

${ }^{39}$ In the canton of Zurich in the peak year of 1855 there were at least 3,000 complaints (from an estimated population of 258,000). Fünf und zwanzigster Rechenschaftsbericht des Obergerichts an den Großen Rath des Standes Zurich über das Jahr 1855 (Zurich, 1856), 34f.; Heiner Ritzmann-Blickenstorfer, ed., Historische Statistik der Schweiz (Zurich, 1996), 94.
} 
especially difficult. ${ }^{40}$ The overseeing authority in one case wrote, "it is easy to make a mistake concerning the true worth of a horse," as another official had done when he recorded a horse — "brown, ca. eight years old" — as collateral for 300 francs, but which only brought seventy-two francs at auction. ${ }^{41}$ Furthermore, employment in rural industries necessitated borrowing and lending. ${ }^{42}$ Within the cottage industry system, raw materials and prefabricated pieces were put out and circulated, and it was sometimes not clear to whom they belonged at any particular moment of time. ${ }^{43}$ Local officials accordingly insisted that cloth, silk thread, and other raw materials should be excluded from the attached property of weavers, because otherwise their employers would be aggrieved. $^{44}$

Certain claims could stand in opposition to the demands of other creditors. This was especially true of wages and board paid in advance, as was the case, when factory owners who had advanced money to their workers reclaimed their prepayment vis à vis the demands of the workers' grocery dealers or other creditors. Thus the garnishing of wages was complicated by the methods of payment and the intermittent nature of wage

\footnotetext{
${ }^{40}$ Petition des Vorsteher der Gesellschaft der Gemeindeammänner des Bezirkes Zurich namens derselben, zum Rechtstriebgesetz, 3 Februar 1842, P 5.2, STAZH.

41 "Regreßanspruch gegen einen Gemeindeammann wegen ungenügender Pfändung," Zeitschrift für Kunde und Fortbildung der zürcherischen Rechtspflege 14 (1864): 5, 1.

${ }^{42}$ The broad spectrum of debt-induced ties to laborers has recently received great attention under the umbrella term "bondage." For a labor historical perspective, see Gwyn Campbell and Alessandro Stanziani, eds., Debt and Slavery in the Mediterranean and Atlantic Worlds (London, 2013); Marcel van der Linden, Workers of the World: Essays toward a Global Labor History, chap. 2 (Leiden, 2008).

${ }^{43}$ The classic studies on the protoindustrial conditions of production in the canton of Zurich are Rudolf Braun's, Industrialisation and Everyday Life, transl. Sarah Hanbury Tenison, (Cambridge, 1990); Rudolf Braun, Sozialer und kultureller Wandel in einem ländlichen Industriegebiet im 19. und 20. Jahrhundert (Erlenbach at Zurich, 1965); and Ulrich Pfister, Die Zürcher Fabriques: protoindustrielles Wachstum vom 16. bis zum 18. Jahrhundert (Zurich, 1992).

${ }^{44}$ Petition des Vorsteher der Gesellschaft der Gemeindeammänner des Bezirkes Zurich namens derselben, zum Rechtstriebgesetz, 3 February 1842, P 5.2, STAZH.
} 
labor. ${ }^{45}$ Only with the normalization of regular monetary wages towards the end of the nineteenth century could the garnishing of future wages become widespread. ${ }^{46}$

Before the federal law of 1892 , attached property was dealt with in a variety of ways. In some Alpine regions there was no auction at all, but rather the seized property was simply turned over to the creditor in lieu of payment. ${ }^{47}$ Supporters of standardizing the legal process viewed this as a sign of economic backwardness. ${ }^{48}$ One pamphleteer called this direct exchange of attached items "a true scandal" and held that if attached property was not subjected to the price mechanism of an auction, a true assessment of its value was impossible: "How should a local official accurately estimate the value of attached materials, paintings, trinkets? He will easily guess too high, too low. And what should a merchant in Berne do with an old dinghy which is transferred to him somewhere on the banks of Lake Lucerne?"49

Seizing someone's property, as judicial officials concurred, was to place a wager in accordance with its monetary value. Experts also agreed, however, that the subjective value of property was higher than this exchange value in the substitution. This referred to the fact that an object always brought less at auction than it was considered to be worth in

\footnotetext{
45 "Inwieweit kann der Arbeitslohn eines Fabrikarbeiters gepfändet werden: "Rekursentscheid vom 29. November 1855," Zeitschrift für Kunde und Fortbildung der zürcherischen Rechtspflege 2 (1855): 247250.

${ }^{46}$ J. H. Gwalter, Das zürcherische Schuldbetreibungsgesetz vom 1. April 1851. Mit Erläuterungen unter vorzüglicher Berücksichtigung der gerichtlichen Praxis (Zurich, 1853), 39; Conrad Jenny: Die Lohnpfändung. Pfändungsbeschränkungen nach Art. 93 des schweizerischen Schuldbetreibungs- und Konkursgesetzes (Aarau, 1912), 25-41.

${ }^{47}$ Alfred Nägeli, Das germanische Selbstpfändungsrecht in seiner historischen Entwicklung mit besonderer Rücksicht auf die Schweiz (Zurich, 1876), 102-105.

${ }^{48}$ On the contemporary impressions of central Switzerland as economically backward after the foundation of the federal state in 1848, see Aram Mattioli, "Die Innerschweiz im frühen Bundesstaat - neue Sichtweisen auf eine wenig bekannte Gesellschaft," in Alexandra Binnenkade and Aram Mattioli, eds., Die Innerschweiz im frühen Bundesstaat (1848-1874): Gesellschaftsgeschichtliche Annäherungen (Zurich, 1999), 11-30.

${ }^{49}$ Zur Volksabstimmung, 8. Similar arguments are made in "Die Obstruktion gegen das schweizerische Schuldbetreibungsgesetz," Der Gerichtssaal: Zeitschrift für schweizerische Civil- und Strafrechtspflege 5, no. 4 (9 January 1889): 9f.
} 
practice. ${ }^{50}$ Commentators observed that a washing trough, sofa, or table made of pine auctioned off to the highest bidder brought in less than it was worth to the household of the debtor. This asymmetry in the disposability of things went along with the compulsory nature of attachment — even though officials emphasized that the seizure and sale was meant not to punish the debtor but rather to satisfy the creditor with money. The discrepancy between the legal assertion that the seizure of property was meant not as punishment but rather as compensation and the material, asymmetrical subjective utility of the respective goods on which the system of debt collection was based points to an internal contradiction of attachment.

The mobilization of goods, intended to enable the "free flow" aimed for in a liberal economy, increased over the course of the nineteenth century as systems of debt collection changed. The legal conception of collateral was not uniform: an object that had been mortgaged based upon the assumption of future appreciation was different than a portable asset that could be carried to the pawnshop or seized in attachment. All these renderings of collateral, however, shared a conception of property as a thing, and in all such cases, the legal distinction between real property and movable assets was significant. ${ }^{51}$ In the case of a mortgage, transferable property was rooted in immovable things. ${ }^{52}$ Over the course of the nineteenth century, these deposits became increasingly liquid, for example when annuities that had once been "in perpetuity" were converted

\footnotetext{
${ }^{50}$ Herbert Conrad, Die Pfändungsbeschränkungen zum Schutze des schwachen Schuldners: eine juristische und sozialpolitische Studie (Jena, 1906), 71.

${ }^{51}$ On the medieval transformations of this Roman law distinction see Howell, Commerce, chap. 1.

${ }^{52}$ On the different forms of mortgage which were typical for the rural credit market in Switzerland, see Markus Mattmüller, Agrargeschichte der Schweiz im Ancien Régime, vol. 2, Vorlesung im WS 1978/79 und SS 1979, (unpublished manuscript, Department of History, University of Basel, 1979), 365-378; Hermann Schulin, "Zur Entwicklung des Grundpfandrechts in der Schweiz", in Helmut Coing, ed., Wissenschaft und Kodifikation des Privatrechts im 19. Jahrhundert, vol. 3, Die rechtliche und wirtschaftliche Entwicklung des Grundeigentums und Grundkredits (Frankfurt, 1976), 373-414.
} 
into bonds that could be terminated.$^{53}$ In Zurich this liquidation of "eternal pensions" occurred in 1853 in the context of an expanding financial sphere and new targets for investment that challenged the privileged position previously held by mortgaged credit. $^{54}$ One observer suggested in 1869 that previously

"it had been left to the goodwill of the bond debtor, whether he paid the interest on time or not; if so, he received a nice tip and a sausage together with a generous drink as a token of gratitude; if not, he received the same as a matter of habit. This is no longer the case; the capital that is not absorbed by the railroad and other joint-stock industries is invested in government bonds with decent interest and maximum profits. ${ }^{, 55}$

The process of collateralization undermined the conceptual distinction between fixed and movable assets, for mortgages on "fixed property" could be converted into freely circulating securities. A judicial expert thus observed in the mid-nineteenth century that "the strange situation has emerged that the claims to mortgaged real estate are included among the movable assets of the creditors and among the real property of the

\footnotetext{
53 "Gesetz über die Ablösung grundversicherter Forderungen überhaupt und über die Natur und Wiederauflösung der durch den Uebergang von Unterpfändern auf dritte Besitzer entstehenden Rechtsverhältnisse insbesondere" [1853], in Officielle Sammlung der seit Annahme der Verfassung vom Jahre 1831 erlassenen Gesetze, Beschlüsse und Verordnungen des Eidgenössischen Standes Zurich, vol. 9, (Zurich, 1853), 280-286.

${ }^{54}$ On the expansion of the financial sphere after mid-century, see Franz Ritzmann, Die Schweizer Banken: Geschichte - Theorie - Statistik (Berne, 1973); Joseph Jung, Alfred Escher (1819-1882): Der Aufbruch zur modernen Schweiz. Bd. 3: Schweizerische Kreditanstalt, Eidgenössisches Polytechnikum, Aussenpolitik (Zurich, 2006). The insitutionalization of credit, however, remained limited, as suggested by this older case study: Arthur Wolf, Ein Beitrag zur Erkenntnis der Verschuldung des bäuerlichen Grundbesitzes im Kanton Zürich. Grundbesitzverteilung und Bodenverschuldung der Gemeinde Waltalingen bei Stammheim, Zürich 1912.

${ }^{55}$ Farner, Gottfried: Der Schuldbriefverkehr und das zürcherische Notariatswesen unter der Initiative (Zurich, 1869), 9. See Martin Schaffner, Die demokratische Bewegung der 1860er Jahre: Beschreibung und Erklärung der Zürcher Volksbewegung von 1867 (Basel, 1982), 189-191.
} 
debtor." ${ }^{, 56}$ Mortgages repeatedly led to confusion about the status of real, fixed property and movable things.

What is more, collateralization not only fabricated abstraction and the transformation of specifics into generalized equivalents, but, even more, it shaped new particularities itself. ${ }^{57}$ The method of collateralization created its own tangibility. This can be illustrated in an example of mortgaged real property. In a period of economic crisis linked to the cotton shortage caused by to the American Civil war, a wave of unsettling arson cases swept through several Swiss cantons in early summer 1867 . A newspaper in Zurich blamed the discrepancy between the plummeting value of the mortgaged real estate compared with the relatively high value for which they were insured. When a bubble in the real estate market collapsed in the 1860 s, real estate prices had bottomed out and banks became extremely reluctant to lend. Insurance values, however, remained high, meaning that "the hard-pressed in their need" who wanted "to avoid going bankrupt" were driven to become Brandteufel (literally, "fire devils," or firebugs). ${ }^{58}$ Whether via the attachment of household utensils, animals, and property titles, demands for credit, or even the ruination of a property, the process of posting collateral transformed these objects. For, as becomes most starkly apparent in the arson case, it was the status of the objects as collateral in processes of commensuration that affected the objects' materiality. What is more, collateral also restructured interpersonal relations. In the course of the nineteenth century, new forms of economic exchange

\footnotetext{
${ }^{56}$ Johann Caspar Bluntschli, "Kommentar zum Sachenrecht," in Privatrechtliches Gesetzbuch für den Kanton Zurich. Mit Erläuterungen, 3rd ed., vol. 2, Sachenrecht, (Zurich, 1861), 11.

${ }^{57}$ For an analysis of this abstraction and particularity within a Marxian framework, see Miranda Joseph, Debt to Society: Accounting for Life under Capitalism, chap. 1 (Minneapolis, 2014).

58 "Der Brandteufel im Kanton Zurich," in Der Republikaner: Zürcher Intelligenzblatt, no. 134 (8 June 1867): 1 .
} 
strengthened not only financial intermediaries, as is recounted in familiar historical narratives on the modernization of credit markets, but simultaneously also restructured the mediative potential of personal relationships. In this context, I would like to point out the practice of co-signing loans, a specific configuration of personhood and debt that collateralized social relationships themselves. By the 1880 s, during a protracted economic crisis, edifying texts, novels, and social interventions warned with heightened urgency about the "dangers of co-signing" a surety. ${ }^{59}$ By that time, banks increasingly required a cosigner to provide an additional security for loans, and social commentators viewed this as a dangerous objectification of social relationships. The supposedly traditional form of intermediation in which persons intervened to guarantee loans gained new importance with the emergence of new financial institutions and in the context of a modern economic crisis.

To preliminarily conclude the argument so far, it is possible to highlight the contradictory roles which collateralization played in legal and economic aspects of everyday life. On one hand, impounding property simplified debt collection. This straightforward administrative procedure made do with a short-cut heuristics. The collateral served as a "placeholder", making complicated appraisal of property values unnecessary and leading to compartementalized knowledge. The social relationship

\footnotetext{
${ }^{59}$ Alexander Isler, "Die Gefahren der Bürgschaft. Warnung vor ihrer Eingehung und Vorschläge zur Abhülfe," Schweizerische Zeitschrift für Gemeinnützigkeit 26 (1887): 339-389; Eduard Thurneysen, Eine offene Wunde unsers Volkslebens: Ein Wort wider das Bürgschaftswesen in unserer Zeit (Zurich, 1888); Gottlieb Egli, "Die Bürgschaft," Der Gerichtssaal: Zeitschrift für schweizerische Civil- und Strafrechtspflege 4, no. 14 (16 February 1887): 72f. A prominent example of a literary rendering of this problematic was Martin Salander, a late work of the national author Gottfried Keller. See Gottfried Keller, Sämtliche Werke. Historisch-Kritische Ausgabe, ed. Walter Morgenthaler et al, vol. 8, Martin Salander (Zurich, 2004 [1886]). On the 1880s crisis in Switzerland, in some respects a late follow-up to the Europewide Gründerkrise, see Thomas Widmer, Die Schweiz in der Wachstumskrise der 1880er Jahre (Zurich, 1992).
} 
implicit in property was relegated to a thing. Collateralization thus provided a simple legal infrastructure for credit transactions. On the other hand, collateralization also created new social ties. To frame an object as collateral did not reduce the intricacies of the social context but rather intensified these. In this sense, the methods of collateralization were prone to irritations: in the interest of enforcing contracts and regulating property relationships, collateralization complicated the relationship between creditors and debtors, and between the categories of persons and things. Borderline cases of collateralization shed light on this twofold effect between entanglement and disentanglement. ${ }^{60}$ The following section addresses two such particularly striking examples in the nineteenth century: pawning and the incarceration of debtors in which the body served as collateral.

\section{Borderline Cases: Pawnbroking and Incarceration of Debtors}

Pawnbroking was a marginal phenomenon in Switzerland, but it opens an exemplary vista on the relationship that linked personhood and objects in the nineteenthcentury imaginary. ${ }^{61}$ Long-term historical studies of pawnbroking in Europe have shown how civil and ecclesiastical authorities and, later, agencies of the bourgeois civil society assumed control of the system of pawnbroking in order to limit it. ${ }^{62}$ In Switzerland the "question of pawnbroking" was dealt with by philanthropic organizations, especially the

\footnotetext{
${ }^{60}$ To take up a terminology coined by Michel Callon. See idem, "Introduction: The Embeddedness of Economic Markets in Economics", in idem, ed., The Laws of the Markets (Oxford, 1998), 1-57.

${ }^{61}$ This was especially true when compared with England. For stories of pawnbroking in the nineteenth century, see Melanie Tebutt, Making Ends Meet: Pawnbroking and Working-Class Credit (Leicester, 1983); Wendy A. Woloson, In Hock: Pawning in America from Independence through the Great Depression (Chicago, 2009); Karl Christian Führer, "Pawning in German Working-Class Life before the First World War," in International Review of Social History 46, no. 1 (April 2001), 29-44; Paul Johnson, Saving and Spending: The Working-Class Economy in Britain, 1870-1939 (Oxford, 1985); Finn, Character of Credit, 76-89.

${ }^{62}$ On the ecclesiastical institution, the montes pietatis, see Fontaine, Moral Economy, chap. 6.
} 
private and predominantly Protestant Gemeinnützige Gesellschaft. Bourgeois

philanthropists hoped to promote virtues of diligence and abstention by institutionalizing savings; pawnbroking was morally precarious in their eyes. ${ }^{63}$ These middle-class

observers of the working-class everyday economy viewed pawnbroking as an "alchemical endeavor," in which personal objects were converted into their monetary values. ${ }^{64}$ The nexus of material deposits and liquid cash struck the philanthropists simultaneously as a relic of a bygone age and a phenomenon of urban hypermodernity. One philanthropist viewed pawnbroking as "an institution of the Middle Ages, which in some regards strangely extends into our own, fundamentally different era. ${ }^{, 65}$ In the nineteenth century, according to this commentator, pawnbroking was obsolete, for capital had become "more liquid" and was accessible to those "less well off." At the same time, however, the anonymity of the "large cosmopolitan metropolis," in which the poor and the rich were largely separated, necessitated pawnbroking, this philanthropist opined. He referred to the example of Paris, where supposedly, at the end of each summer, "twenty thousand parasols" found their way into pawnshops and twenty-eight million francs were thus "shut up in the pawnshop as though dead." ${ }^{, 66}$ In the eyes of bourgeois commentators, pawnshops served as "institutions for the support of squandering" because the practice of

\footnotetext{
${ }^{63}$ At the beginning of the century, the Gemeinnützige Gesellschaft was quite successful in its primary effort to found local savings banks: by 1860 , every fourth resident of the canton of Zurich had a savings account pass book. On the growth and ideology of the savings banks in nineteenth-century Switzerland, see Mischa Suter, "Ökonomischer Individualismus und moralischer Paternalismus. Sparkassen im Kanton Zurich während der Zeit des Pauperismus (um 1820-1860)," in Thomas David, et al, eds., Die Produktion von Ungleichheiten - La production des inégalités (Zurich, 2010), 133-144; Ritzmann, Schweizer Banken, 23-36. See also Beatrice Schumacher et al., Freiwillig verpflichtet: Gemeinnütziges Denken und Handeln in der Schweiz seit 1800 (Zurich, 2010).

${ }^{64}$ W. Schmidlin, "Ueber Pfand- und Leihhäuser (monts de Piété): Referat in der Versammlung der Schweizerischen gemeinnützigen Gesellschaft zu Basel den 22. September 1864,” Schweizerische Zeitschrift für Gemeinnützigkeit 4 (1865): 67.

${ }^{65}$ J. L. Spyri, "Ueber Pfand- und Leihhäuser," in Schweizerische Zeitschrift für Gemeinnützigkeit 3 (1864): $235-253$.

${ }^{66}$ Spyri, "Ueber Pfand- und Leihhäuser," 235.
} 
pawning threatened to obscure the limits between subjective needs and objective means. ${ }^{67}$

From this perspective, pawnbroking was a liminal practice, strangely located between medieval "alchemical" exchanges and an anonymous, metropolitan modernity. According to this view, pawnbroking packed objects away as dead capital and animated quixotic desires.

Although pawnbroking was criticized as an antiquated mechanism, the pledged objects were often decidedly modern, as is perhaps epitomized in the pocket watch, a liberal object par excellence. ${ }^{68}$ Pocket watches were initially a moderate luxury object, but the prices sank starting in the 1870s and they soon became affordable objects which could also be easily liquefied. ${ }^{69}$ Timepieces and jewelry of silver and gold made up nearly half the objects pawned in the city of Basel at the end of the nineteenth century. ${ }^{70}$ For gold and silver jewelry, pawnbrokers gave loans for up to 80 percent of the material value; other objects could be pawned for approximately two-thirds of their market value. ${ }^{71}$ Priority was given to personal effects with clear delineation of personal property, which did not affect the interwoven relationship of protoindustrial production. The founders of such an establishment in Basel emphasized that they would not accept silk or other raw materials for fabrication as collateral. ${ }^{72}$

\footnotetext{
${ }^{67}$ Spyri, "Ueber Pfand- und Leihhäuser," 245.My turn of phrase is indebted to Simmons, "Minimal Frenchmen: Science and Standard of Living, 1840-1960" (PhD diss., Univ. of Chicago, 2004), 448.

${ }^{68}$ Chris Otter, "Making Liberal Objects: British Techno-Social Relations 1800-1900," Cultural Studies 21, nos. 4-5 (June 2007): 570-590, esp. 577.

${ }^{69}$ Here and subsequently, Messerli, Gleichmässig, 149-151.

${ }^{70}$ Berichte der Basler Pfandleih-Anstalt 1884/85-1904/05, H + I D 601, SWA.

71 "Reglement für die Mobiliarleihkasse der Zürcher Kantonalbank (vom 30. Weinmonat 1871)," inOffizielle Sammlung der seit 10. März 1831 erlassenen Gesetze, Beschlüsse und Verordnungen des Eidgenössischen Standes Zurich, vol. 15 (Zurich, 1873), 552, § 10; Bericht der Basler Pfandleih-Anstalt über die erste Geschäftsperiode vom 15. Januar 1884 bis 30 . Juni 1885 , genehmigt durch die Actionärsversammlung am 11. November 1885, Basel 1885, H + I D 601, Schweizerisches Wirtschaftsarchiv Basel (hereafter SWA), 6.

${ }^{72}$ Über die Gründung einer Mobiliar-Leihkasse in Basel, in Verbindung mit einer Handwerker-Bank (Basel, 1864), 17.
} 
Proponents of the pawning system - in Basel these came from among the ranks of lower craftsmen — emphasized that pawnbroking made the movable goods of a household productive. If the income of a household was insufficient, then this "minor capital tied up in the movable property" provided the only access to credit. ${ }^{73}$ This also benefited those business owners who had opened accounts for these families. ${ }^{74}$ Pawnbroking was thus seen to stabilize the relationship of exchange beyond the limits of the working class. On the other end of the spectrum, bourgeois philanthropists employed the rhetoric about discipline and frugality. ${ }^{75}$ However, the suggestion that pawnbroking should be a type of "alchemy" goes further: it points to the particularity and the liquidation of objects. In the eyes of the bourgeois philanthropists, these objects were meant for the individual's use alone. From this perspective, the shift of intimate objects from the register of private property to the provider of a financial guarantee represented an impermissible misappropriation. The pawnshop made the contradiction between the particularity of the object and its exchange value clear. It fed the anxiety of middle-class commentators that objects to which one had an intimate relationship could be exchanged for anonymous currency. ${ }^{76}$ The corresponding values did not lend themselves to abstraction, they did not disappear, but remained material and visible in the objects stored in the pawn shop. This made the phenomenon difficult to classify; it appeared as liminal relations that seemed to embody simultaneously medieval backwardness and urban, modern anonymity.

\footnotetext{
${ }^{73}$ Mont de Piété in Basel, 20.

${ }^{74}$ Mont de Piété in Basel, 15.

${ }^{75}$ For expressions of concern about the control of consumption, see Woloson, In Hock, 112.

${ }^{76}$ Peter Stallybrass, "Marx' Coat," in Patricia Spyer, ed., Border Fetishisms: Material Objects in Unstable Spaces (New York, 1998), 196.
} 
A parallel, if somewhat different problematic of exchangeability and materiality can be found in the incarceration of debtors. The attachment of persons in debtors' prison created a conundrum in which the problem of offsetting bodies and values, the objectification of the person and the freedom of property, became especially apparent. Debtors' prisons preoccupied the political imaginary in a variety of national contexts: ${ }^{77}$ countless commentators have denounced the nexus of monetary value and persons, of private and public rights, as atavism in need of civilization. ${ }^{78}$ Comparative historical studies show that detention of the debtors' bodies was most common where the seizure of their property was legally complicated, as was the case, for example, in England.$^{79}$ For the French case, historian Erika Vause has shown how incarceration served as an intermittent method of coming to terms with the mobile, mercantile economy. ${ }^{80} \mathrm{In}$ countries where it was relatively easy to attach property, like in Switzerland, such arrests were of marginal importance. Also, the denunciatory rhetoric surrounding debtors' prisons was basically absent in Switzerland. Although imprisonment for debt was addressed only offhandedly in Switzerland, elements of a rhetoric of progress were

\footnotetext{
${ }^{77}$ I borrow the term "political imaginary" from Susanne Lüdemann, Metaphern der Gesellschaft: Studien zum soziologischen und politischen Imaginären (Munich, 2004), in her interpretation of Cornelius Castoriadis, The Imaginary Institution of Society, trans. Kathleen Blamey (Cambridge, MA, 1987). ${ }^{78}$ On the role of ritual in debtors' prisons, see Gustav Peebles, "Washing Away the Sins of Debt: The Nineteenth-Century Eradication of the Debtors' Prison," Comparative Studies in Society and History 55, no. 3 (July 2013): 701-724; Bruce H. Mann, Republic of Debtors: Bankruptcy in the Age of American Independence, esp. chap. 5, (Cambridge, MA, 2003); Sergei Antonov, "Law and the Culture of Debt in Moscow on the Eve of the Great Reforms, 1850-1870," esp. chap. 5 (PhD diss., Columbia University, 2011).

${ }^{79}$ V. Lester, Victorian Insolvency: Bankruptcy, Imprisonment for Debt, and Company Winding-Up in Nineteenth-Century England (Oxford, 1995), 89; Amanda Bailey, Of Bondage: Debt, Property, and Personhood in Early Modern England, (Philadelphia, 2013), 7; Thomas M. Luckett, "Credit and Commercial Society in France, 1740-1789" (PhD diss., Princeton, 1992), 105. Luckett references Paul Hess Haagen, "Imprisonment for Debt in England and Wales," (PhD diss., Princeton, 1986), 1, 28-30; Christoph Bergfeld, "Über die Aufhebung der Schuldhaft in Frankreich und in Deutschland," in JeanFrançois Kervégan, ed., Wechselseitige Beeinflussungen und Rezeptionen von Recht und Philosophie in Deutschland und Frankreich (Frankfurt, 2001), 329-378.

${ }^{80}$ Vause, "Disciplining the Market," 653, 664, 671.
} 
nevertheless present in the few deliberations on the subject: attachment of individuals was only known in a "few" remaining cantons, wrote a legal author in 1858, who then, paradoxically, went on to name a number of industrial centers in addition to Zurich: Basel, Vaud, Geneva, Berne, as well as Neuchâtel and Valais. ${ }^{81}$ In that sense, although incarceration existed, it led to very few conflicts with the legitimizing repertoire of the liberal imagination. This was due at least in part to the fact that there was not a consistent model of incarceration in Switzerland. In the mercantile urban canton of Geneva, for example, only merchants who had tried to shirk their financial liabilities were incarcerated (mirroring French laws). ${ }^{82}$ In the protoindustrial and industrial canton of Zurich, on the other hand, incarceration for debt evolved from an instance for evaluation to a means of coercion employed against the fully destitute. ${ }^{83}$ In such cases, taking possession of the body, which represented the goods of a person, was typically meant as a further type of substitution, namely, the enforcement of payment in installments. Theoretically creditors did not consider themselves compensated by the incarceration of their debtors, but the imprisoned body was seen as a stand-in for the debtor's property. Also, imprisonment was not considered a punishment, but a temporary means of execution. In the eighteenth century, incarceration for debt was meant as a "scare tactic" ("Schreckmittel," as contemporaries called it) to discipline and hold obstinate debtors

\footnotetext{
${ }^{81}$ Fr. von Wyß, "Die Schuldbetreibung nach schweizerischen Rechten," Zeitschrift für schweizerisches Recht 7 (1858): 113. A comparative legal study emphasized in 1870: "Il est evident qu'en Suisse comme partout la contrainte par corps aura bientôt fait son temps." Alphonse Rivier: "De la contrainte par corps en Suisse," in Revue de droit international et de législation comparée 2 (1870): 52.

${ }^{82}$ On the decades-long debate in France about who should be considered "commerçant" see, Erika Vause, "In the Red and in the Black: Bankruptcy, Debt Imprisonment, and the Culture of Credit in PostRevolutionary France" (PhD diss., Univ. of Chicago, 2012); Erika Vause, "Disciplining the Market: Debt Imprisonment, Public Credit, and the Construction of Commerical Personhood in Revolutionary France," Law and History Review 32, no. 3 (August 2014): 647-682.

${ }^{83}$ In some respects this mirrors the development in England, as shown by Margot Finn, where imprisonment for debt increasingly became a coercive means against working-class debtors. Finn, Character of Credit, 151, 154.
} 
until their financial situation could be determined and their property inventoried. ${ }^{84}$ If the debtors declared bankruptcy, they were released. Around 1800, however, this changed. ${ }^{85}$ Incarcerated debtors were increasingly those who were determined to be completely destitute and to possess nothing of value. Incarceration was used more and more often to exert pressure on the debtor. In this way, the threat of incarceration was present in the liberal era. The scant statistics available show that the number of arrest warrants rose during the crisis in the 1860 s, even if, after 1851, such warrants could be issued only at a judge's discretion, meaning that creditors could no longer expect to have a warrant automatically issued if they demanded it. ${ }^{86}$ In Zurich and Geneva alike, the number of incarcerations was consistently lower than the number of warrants issued, and imprisoned debtors were typically released within a few days. ${ }^{87}$ Debtors made up only a small fragment of the prison population and were incarcerated locally. ${ }^{88}$ Of the median 858 warrants issued annually in the years $1860-1868$ in Zurich, for example, only a small fraction resulted in imprisonment and the number of warrants is dwarfed by the median almost 140 '000 first dunning letters officially issued every year. Comparing the number

\footnotetext{
${ }^{84}$ Satz- und Ordnungen eine frey-loblichen Statt-Gerichts zu Zurich, vol. 3, "Wie die Schuldner zu suchen und was Gewalt das Gericht haben solle?" (Zurich, 1715), 27, § 19; Gottfried von Meiss, Das Pfand-Recht und der Pfand- oder Betreibungs-Proceß in seinem ganzen Umfang: Nach den Gesetzen und der Uebung des Eidgen. Cantons Zürich / Ein civilrechtlicher Versuch (Zurich, 1821), 120.

${ }^{85}$ At first this was a matter of customary law, and in 1812 it was codified in a decree of the Council of States. Compare: "Circulare des Kleinen Raths vom 28sten Januar 1812, an sämmtliche Bezirks- und Unerstatthalter und die Bezirksgerichte, betreffend die Behandlung des Rechtstriebs für laufende Schulden, vorzüglich der Pfändung, und die Ertheilung und Anwendung des Wortzeichens," in Officielle Sammlung der von dem Großen Rathe des Cantons Zurich gegebenen Gesetze und gemachten Verordnungen, und der von dem Kleinen Rath emanierten allgemeinen Landes- und Polizey-Verordnungen, vol. 5 (Zurich, 1813), 248-252. Erich Appenzeller, Der Schuldverhaft und seine Abschaffung nach den Gesetzgebungen der schweizerischen Kantone und des Bundes (Langensalza, 1923), 15; Eduard Berdecki, Die Einflüsse der Aufklärung auf die Schuldhaft in den deutschen Staaten und in der Schweiz (Basel, 1959), 58.

${ }^{86}$ The analysis was done with data from 1860-1868, the last full year before the constitutional revisions of 1869 abolished the incarceration. See Rechenschaftsberichte des Obergerichtes 1860-1868.

${ }^{87}$ On the length of incarceration in Geneva, see P.F. Bellot, Loi sur la procédure civile du Canton de Genève, suivie de l'Exposé des motifs, 2nd ed., seule compl. / par Schaub, Odier et Mallet (Paris, 1837), $655 f$.

${ }^{88}$ STAZH P 296 Bezirksgefängnisse; STAZH P 300.1.2, Gefängniswesen, Bezirksgerichte.
} 
of warrants with the number of debtors who were declared bankrupt - a median 268 for the same period -, however, provides evidence of the considerable impression left by such incarceration. ${ }^{89}$ It seems that incarceration was generally an incidental method to exert pressure on destitute debtors, and it was quietly abolished, first within the canton with the revision to the constitution in 1869 , and then at the federal level in $1874 .{ }^{90}$ Overall, from a method to pin down debtors and to scrutinize their property relations that is, an investigative means - , imprisonment developed into a means of coercion to pressure debtors to mobilize their kinship ties, or other relations, to cover the debt.

One of the few voices to criticize the knowledge practices related to debt imprisonment as inherently contradictory was that of the former mayor of Zurich, Conrad Melchior Hirzel, in a hearing which is preserved only in manuscript form and was probably never printed for distribution. ${ }^{91}$ In Hirzel's view, incarceration did not lead to transparency and a reasoned access to the debtor's property, but it did create great confusion and arouse uncontrolled passions. It was "obviously capricious" that warrants were routinely issued for debtors who had already declared themselves insolvent. ${ }^{92}$ As a temporary measure to detain a debtor while an inventory of his property could be taken, incarceration was a defensible measure. However, as soon as bankruptcy had been officially established, the debtor should be released. Anything else threatened to "destroy the consistency and the stability of different parts of our laws," according to Hirzel. ${ }^{93}$ Detention of those absolutely unable to pay their debts served no purpose. Moreover, the

\footnotetext{
${ }^{89}$ See Rechenschaftsberichte des Obergerichtes 1860-1868; Ritzmann-Blickenstorfer, ed., Historische Statistik der Schweiz.

${ }^{90}$ Rivier, "contrainte par corps", 47.

${ }^{91}$ C[onrad] M[elchior] Hirzel, "Dissertation über das Wortzeichen," (undated manuscript, prior to 1842), P 37, STAZH.

92 Ibid., part 1, p. 6.

${ }^{93}$ Ibid., part 1, p. 9.
} 
authority of official knowledge, which vouched for the procedures of a declaration of bankruptcy, were undermined by the incarceration.

Instead of fairly distributing the assets to be liquidated among all the creditors according to established rules, incarceration threatened to become a campaign by one single "revengeful creditor" seeking to throw the "black fortune of an anxious, fleeting, outlawed life" over his debtor. ${ }^{94}$ Instead of being a legal measure, incarceration of the debtor took place outside of the law. And instead of being a systematic instrument, imprisonment fueled uncontrolled affects. The public should view creditors who sought to use this method as "hardhearted and zealous." 95 On the other hand, hypothesized Hirzel, when faced with prison, the debtor was prepared to "take the most desperate of measures" in order to "hold off the rolling wheel of his fortune." This encouraged secret negotiations between debtors and unscrupulous creditors and gave dishonesty the upper hand over honesty. In fact, legal means would thereby become an "object for sale, which might be put on the market [...]." ${ }^{, 96}$ Unlike the methodical attachment of property, in Hirzel's opinion imprisonment for debt created new intransparencies. Hirzel's concern was not characterized by universal, abstract views of freedom and property. Again, for an extensive investigation into a debtor's financial situation, Hirzel approved of detention. The problem was not a fundamental incommensurability between body and collateral. In fact, Hirzel highlighted what the balancing of body and collateral entailed: instead of clarity, new confusion, and instead of predictability, an increased zeal which ran the knowledge practices of the bankruptcy process into the ground.

\footnotetext{
${ }^{94}$ Ibid., part 2, p. 23.

${ }^{95}$ Ibid., part 2, p. 10.

${ }^{96}$ Ibid., part 2, pp. 11, 8 .
} 
If the body represented collateral, which in mid-century was increasing

repossessed, the body was not simply an equivalent of money, but rather its incarceration was an impetus for a new settlement, incremental repayment. In this respect the problem, as recognized by the few Swiss critics of the practice of debtor incarceration, was not so much a fundamental incommensurability between body and collateral, but rather that the collateralization of the body created new incalculability because the incarceration undermined the established knowledge practices associated with bankruptcy proceedings.

\section{Contouring the Unattachable Minimum}

Parallel to the attachment of objects, human bodies, animals, titles, and entitlements, legal practices shaped the limits of the "unattachable." One legal thinker suggested a "right of necessity" which should stipulate that a set of indispensable objects to be left to the debtor. In both the Elements of the Philosophy of Right and in his lectures concerning legal philosophy, Georg Friedrich Wilhelm Hegel referred to the so-called benefit of competence, meaning that a craftsman "was left the tools of his trade, and a farmer his field," and that these were excluded from attachment. ${ }^{97}$ The right of necessity was accordingly employed "not only in extreme cases," but rather in everyday contexts. ${ }^{98}$ For Hegel, these unseizable objects represented a baseline, necessary in order to participate in the legal sphere at all, "for the alternatives are an infinite injury [Verletzung] to existence with total loss of rights, and an injury only to an individual and

\footnotetext{
${ }^{97}$ Georg Friedrich Wilhelm Hegel, "Philosophie des Rechts: Die Vorlesung von 1819/20 in einer Nachschrift," ed. Dieter Henrich (Frankfurt, 1983), 100. As an introduction: Wolfgang Schild, "Hegels Lehre vom Notrecht," in Vittorio Hösle, ed., Die Rechtsphilosophie des deutschen Idealismus (Hamburg, 1989).

${ }^{98}$ Georg Wilhelm Friedrich Hegel, Vorlesungen: ausgewählte Nachschriften und Manuskripte, vol. 14, Vorlesungen über die Philosophie des Rechts Berlin 1819/1820, trans. Johann Rudolf Ringier, eds. Emil Angehrn, Martin Bondeli, and Hoo Nam Seelmann (Hamburg, 2000), 61.
} 
limited existence of freedom, whereby right as such and the capacity for rights of the injured party, who has been injured only in this specific property, continues to be recognized. ${ }^{, 99}$ The right of necessity did not come from a sphere far-removed from the law, but was rather situated in the positive law. Nevertheless, the right of necessity provoked a "collision" or irresolvable situation, for the property rights of the creditor continued to exist even though the right of necessity meant that they were temporarily suspended. ${ }^{100}$ The right to property and the right of subsistence were neither completely incommensurable nor definitively ranked: the liberal legal theoretician Carl von Rotteck viewed the right of necessity as a "contradiction of truths," which risked that "logic might no longer have a place in legal doctrine."101

The Swiss legal system lacked such intricate legal reasoning, but it, too, recognized the benefit of competence in which an object-based conception of property corresponded to knowledge practices. Until the implementation of the federal law in 1892, the category of the "indispensable" remained narrow and material. The minimum was quasi sequestrated in things, so to speak. This constellation benefited the division of subject and object in liberalism, ${ }^{102}$ for it provided for clearly defined material values instead of suspiciously inconsistent, potentially insatiable "needs." In the canton of Zurich in the 1830s, such exclusions applied to a family's hymnals, to the children's schoolbooks, the clothing of the wife and children, and to the "indispensable" clothing of

\footnotetext{
${ }^{99}$ G.W.F. Hegel, Elements of the Philosophy of Right, ed. Allen W. Wood, trans. H.B. Nisbett (Cambridge, 1992), 154. My reading of Hegel's law of necessity draws heavily on the lectures of Daniel Bensaïd, Les dépossédés: Karl Marx, les voleurs de bois et le droit des pauvres (Paris, 2007); and Frank Ruda, Hegel's Rabble: An Investigation into Hegel's Philosophy of Right (London, 2011).

${ }^{100}$ Georg Wilhelm Friedrich Hegel, Vorlesungen über Rechtsphilosophie 1818-1831, vol. 2, Die "Rechtsphilosophie" von 1820 mit Hegels Vorlesungsnotizen 1821-1825, ed. Karl-Heinz Ilting (Stuttgart, 1974), 460.

${ }^{101}$ Carl von Rotteck, Lehrbuch des Vernunftrechts und der Staatswissenschaften, vol. 1, Allgemeine Einleitung in das Vernunftrecht; Natürliches Privatrecht, 2nd exp. ed. (Stuttgart, 1840), 156.

${ }^{102}$ Otter, "Making Liberalism Durable," 4-5.
} 
the debtor himself, as well as objects that had been acquired from an institution (military, poor relief, or the fire department). In 1842, gifts to the children from their godparents were added to this list, as were, in mid-century, implements for cooking and beddingwhich initially included blankets and pillows and later bedsteads and mattresses. Inconsistencies persisted in the regulations of tools and objects integral to the family's livelihood (dung, but also cooking utensils). The set of indispensables had originally included those things via which the household was linked to the community at large. In the late nineteenth century, legal thought understood these unattachable objects to be covered by public law or "common welfare." ${ }^{103}$ The federal law of 1892 expanded the category of "indispensables" considerably. It incorporated the rules of French-speaking Switzerland, which had been in turn influenced by the more comprehensive stipulations of French law, and the German civil procedure code of $1877 .{ }^{104}$ The debate over who should control household objects at the end of the nineteenth century came at a moment in which institutional bodies were rapidly expanding to deal with the problems they perceived in an urbanizing, industrializing society. Under the auspices of the nascent welfare state, public administration, bodies of scientific expertise, commercial and philanthropic organizations, and the labor movement ushered in new forms of knowing. At the same time, these institutions attempted to standardize social practices within the

\footnotetext{
${ }^{103}$ Alexander Reichel, "Giebt es ausser den in Art. 92 des B.G. über Schuldbetreibung und Konkurs aufgeführten Kompetenzstücken noch andere Vermögensgegenstände des Schuldners, welche aus civilrechtlichen Gründen unpfändbar sind?," Zeitschrift für schweizerisches Recht new ser. 13 (1894): 5579.

${ }^{104}$ The relevant passages in French law are in the Code de procédure civile français (§§ 581-582, 593) and for the German context in the German Zivilprozessordnung ( $\S ~ 715,749)$. Cited from Leo Weber and Alfred Brüstlein, Das Bundesgesetz über Schuldbetreibung und Konkurs für den praktischen Gebrauch erläutert (Zurich, 1890), 86.
} 
fabric of the national state. ${ }^{105}$ Although they were controversial from the very beginning, statistics provided the central measurement in this discussion over the objectification of the "social question." 106 A popular legal periodical postulated that the federal law, by expanding the category of indispensable household objects, was, with regards to the social question, "more important than all the laws regulating liability, accident insurance, and alcohol together." 107 The "politics of the necessary" were thus renegotiated and the minimum became a key social category. ${ }^{108}$

Some commentators argued that consumers' creditworthiness would be eroded if wages and household assets could be attached only in part. ${ }^{109}$ Construction workers relied on credit in the winter months, and without the guarantee of their future wages, shopkeepers would give them no credit. ${ }^{110}$ Other observers saw this as a welcome disciplinary measure that would force working-class consumers to pay more frequently in

\footnotetext{
${ }^{105}$ For example, the first statistical annual report (Statistische Jahrbuch) in Switzerland appeared in 1891: Jakob Tanner, "Der Tatsachenblick auf die 'reale Wirklichkeit': zur Entwicklung der Sozial- und Konsumstatistik in der Schweiz," Schweizerische Zeitschrift für Geschichte 45, no. 1 (1995): 98. Peter Wagner, “'An Entirely New Object of Consciousness, of Volition, of Thought.' The Coming into Being and (almost) Passing Away of 'Society' as a Scientific Object," in Daston, ed., Biographies of Scientific Objects, 155. On the development of institutions for collective bargaining in Switzerland in the 1880s, see Erich Gruner, ed., Arbeiterschaft und Wirtschaft in der Schweiz 1880-1914, vol. 2.1, esp. chap. 3 (Zurich, 1988).

${ }^{106}$ On the controversial background of statistics at the dawn of the nineteenth century, see Tanner, "Tatsachenblick”; Regina Wecker, “ “... ein wunder Punkt für das Volkszählungswesen.' Frauenarbeit und Statistik an der Wende vom 19. zum 20. Jahrhundert," in Schweizerische Zeitschrift für Geschichte 45, no. 1 (1995): 80-93; Hans-Ulrich Jost, Von Zahlen und Macht. Statistiker, Statistik und politische Autoritäten in der Schweiz, 18.-20. Jahrhundert (Berne, 1995).

107 “Ein Gesetz von eminenter Tragweite," Der Gerichtssaal: Zeitschrift für schweizerische Civil- und Strafrechtspflege 3, no. 3 (8 January 1887): 9f.

${ }^{108}$ Simmons, Vital Minimum. On the example of a minimum of nutrition in Switzerland, see Jakob Tanner, Fabrikmahlzeit: Ernährungswissenschaft, Industriearbeit und Volksernährung in der Schweiz 1890-1950, chap. 4 (Zurich, 1999).

${ }^{109}$ P. Speiser (Basel), Gutachten über den Entwurf eines eidg. Betreibungs- und Konkursgesetzes, erstattet an das eidg. Justizdepartement am 31. Dezember 1885, E22 1000/134 2611, Schweizerisches Bundesarchiv Bern (cited henceforth as BAR).

${ }^{110}$ Archiv für Schuldbetreibung und Konkurs 2 (1893), 50f. For another view on this question, see "Schädigung des Kredits?," Der Gerichtssaal: Zeitschrift für schweizerische Civil- und Strafrechtspflege 6, no. 91 (13 November 1889): 371.
} 
cash. ${ }^{111}$ A legal journal pointed out that in the first years after the introduction of the federal law, the officials had been reluctant to attach wages due to the lack of precedent. Objects excluded from attachment were easier to measure than monetary wages. ${ }^{112}$ The legal regulations of indispensable objects were supposed to discipline, mold, and assess debtors. The suspicion remained that, given the number of indispensable, unattachable objects, it would no longer be possible to collect smaller sums. ${ }^{113}$ In the first months after the law was introduced, satirical newspaper articles circulated about cunning debtors who, faced with imminent attachment, transferred all their assets into objects that were excluded from such seizure. ${ }^{114}$ According to the federal law, the objects that had been declared indispensable could not be replaced with a respective monetary value. A workers' organization demanded to no avail that craftsmen should be allowed to retain raw materials necessary for one month's work and that the unemployed should have their payments deferred. ${ }^{115}$ A newspaper supportive of the state paid especial attention to insurance payments which were only partially attachable under the proposed law. It welcomed this as a method of encouraging individuals to "strive for financial security."116

\footnotetext{
111 “Zur Volksversammlung in der Tonhalle,” Neue Zürcher Zeitung, no. 316 (12. November 1889): sect. 1, p. 1. Similarly: G. Wolf, Verhältniß der Wohnungs-Vermiether \& -Miether zum neuen Konkurs- und Betreibungsgesetz, mit einem Vorwort betreffend die übrigen Neuerungen im Betreibungsverfahren (Zurich, n.d.), 16.

112 "Eine Enquête über das Existenzminimum," Rechtsfreund in Betreibungs- und Konkurssachen 6, no. 1 (1906): $1-7$.

${ }^{113}$ This was according to a justice of the peace at an event in Schaffhausen, who claimed that around 70 percent of all claims could not be collected due to the number of objects deemed to be indispensable. Neue Zürcher Zeitung, no. 310 (6 November 1889): morning issue, p. 2.

114 "Woher kommt das Mißtrauen gegen die moderne Rechtspflege [Teil] III," Schweizer Kriminal-Zeitung: Organ für Kriminal-, Polizei- und Civil-Gerichtspflege, Unterhaltung und Humor 25 (24 June 1893), 1f; "Um das Konkursgesetz herum," Schweizer Kriminal-Zeitung: Organ für Kriminal-, Polizei- und CivilGerichtspflege, Unterhaltung und Humor, no. 32, (12 August 1893): 4.

${ }^{115}$ Grütliverein, "Petition betreffend den Entwurf eines eidg. Schuldentrieb- und Konkursgesetzes," St. Gallen, late January 1887, E22 1000/134 2611, vol. 3, BAR.

${ }^{116}$ Neue Zürcher Zeitung, no. 306 (2 November 1889): 1.
} 
As historian Dana Simmons has argued, assessing basic minimal needs is essentially "a political act", for it means "defining what is universal and law-like, and what is contingent". ${ }^{117}$ The debate among experts, politicians, and businesspeople about the limitations of attachment dealt primarily with objects. A "low measured, middling lifestyle" was "fixed as the norm", as a contemporary legal dissertation expressed it. ${ }^{118}$ Wedding rings were never attachable, while pictures with Biblical motifs were, except for "actual pictures of saints"; the question as to whether a man's coat belonged to the indispensables or not was answered in the affirmative in the case of a travelling merchant, but negatively in that of a rural man. Although pocket watches of factory workers were initially controversial, officials quickly declared them to be excluded from attachment; the same was true of sewing machines with which some female debtors worked on the side. ${ }^{119}$ A wardrobe or a chest of drawers, a washstand, a table, and one chair per person were to be left in the dwelling — and, in one case, a sofa which served as a child's bed, as well. ${ }^{120}$ Legal institutions debated the question as to whether children should be expected to share a bed, but the majority supported this. ${ }^{121}$ The officials executing the seizure, however, could insist that an expensive bedstead be traded for a simpler one. ${ }^{122}$ The theory and practice were expressly meant not to ensure a lifestyle befitting a person's status but rather to balance the standard for a "recognized level in

${ }^{117}$ Simmons, Dana: Vital Minimum: Need, Science, and Politics in Modern France, Chicago 2015, 1.

${ }^{118}$ Eugen Meier, Die Beschränkung der Zwangsvollstreckung (Lehre von den Kompetenzstücken) nach schweizerischem Recht. Mit einer allgemein-geschichtlichen Einleitung, (Zurich, 1907), 78.

${ }^{119}$ See, in order of the objects mentioned, Meier, Beschränkung der Zwangsvollstreckung, 103, 99, 102, 78, 103; Jakob Messerli, Gleichmässig - pünktlich - schnell: Zeiteinteilung und Zeitgebrauch im 19.

Jahrhundert in der Schweiz (Zurich, 1993), 147f; Meier, Beschränkung der Zwangsvollstreckung, 78, 104, 116.

${ }^{120}$ Meier, Beschränkung der Zwangsvollstreckung, 104.

${ }^{121}$ Entscheidungen des Schweizer. Bundesgerichtes aus dem Jahre 1901. Amtliche Sammlung, vol. 27, part 1, no. 41 (Lausanne, 1902), $246 \mathrm{f}$.

${ }^{122}$ Entscheidungen des Schweiz. Bundesgerichtes aus dem Jahre 1898. Amtliche Sammlung: SeparatAusgabe der betreibungs- und konkursrechtlichen Entscheidungen, vol. 1 (Lausanne, 1899), $284-287$. 
need of protection. ${ }^{, 123}$ Here, too, one can speak of a process of normalization qua objects. This normalization, however, was thwarted time and again. One reason for that is the extent to which objects became charged with great meaning. The objects exempt from seizure seemed to be connected to the personhood of the individual in default. The relationship of the person to property was seen in liberalism as a connection worthy of significant protection. Attachment was necessary to guarantee the property rights of creditors. All the same, the seizure of property, as was involved in attachment, was a tricky proposition for the legal imagination. Here objects provided a means for a taxonomical method of assessing worth and needs, as the indispensable objects exempt from seizure were projected on a generalized level of basic needs.

\section{Conclusion}

It is "necessary to allow for the modern notion that debt enforcement is an act against property and not an act against the personhood" of the individual involved, observed Alfred Brüstlein in 1893, one of the authors of Switzerland's Federal Statute on Debt Enforcement and Bankruptcy, which had been implemented the previous year. ${ }^{124}$ In the nineteenth century, the problem of how to distinguish "actions against property" from those "against personhood," as the legal expert Brüstlein deemed appropriate, proved to be intractable. Within these ongoing difficulties, the conditions for economic exchange appeared increasingly charged in the 1880s. An increased criticism of debt relationships came at a moment in which the expansion of administration, science, philanthropy, and

\footnotetext{
${ }^{123}$ Meier, Beschränkung der Zwangsvollstreckung, 78.

${ }^{124}$ Alfred Brüstlein, "Vorläufige Vorschläge für die Revision des Betreibungsgesetzes," unpublished manuscript of a lecture held on 18 June 1893 in the chamber of commerce in Berne, E22 1000/134 2645, BAR.
} 
the labor movement had made the social an object of observation and intervention. ${ }^{125}$ In this context, as has been argued here, the material relationship of debts for which liberalism established legal regulations became significant. In regards to collateralization, the "federal statute on debt enforcement and bankruptcy" of 1892 marked a compression of the relationships between persons and things that helped to stabilize debt relationships. In conclusion, I would thus like to venture a conceptual generalization while discussing the changing shapes of the collateralization's knowledge practices.

The collateralization of objects required a robust technical legal routine, which promoted the compartmentalization of knowledge. The relationality of debts was corralled by rudimentary methods of notation and was transferred to attached objects. Collateralization was primarily a moment of closure. Unlike complicated bankruptcy proceedings, the seizure of objects allowed for an inconspicuous administrative process and avoided a certain problematic of knowledge. Collateralization thus lay along a trajectory with a conceptual division of subject and object which had paved the way for liberalism, and which was meant to facilitate the free circulation of money, objects, information, and people. In the eyes of bourgeois philanthropists, the practice of pawnbroking provoked liminal relationships between persons and objects in which the disentanglement of exchange value and use value failed. The form of knowledge, however, which was key in the incarceration of debtors, was investigative. In the face of a mobile economy, it seemed thus permissible to take control of the debtor's body while an

\footnotetext{
${ }^{125}$ This has been emphasized by historians writing in a broad Foucauldian perspective, including Jacques Donzelot, L' invention du social: essai sur le déclin des passions politiques (Paris, 1994 [1984]); François Ewald, L'état providence (Paris, 1986); Christian Topalov, Naissance du chômeur 1880-1910 (Paris, 1994); Wagner, "Object of Consciousness"; George Steinmetz, Regulating the Social: The Welfare State and Local Politics in Imperial Germany (Princeton, 1993); James Vernon, "The Ethics of Hunger and the Assembly of Society: The Techno-Politics of the School Meal in Modern Britain," American Historical Review 110, no. 3 (June 2005): 693-725.
} 
inventory of the debtor's property was compiled. In addition, in the first two-thirds of the nineteenth century, incarceration served in a mediating capacity for a system of repayment via installments that could be negotiated and enforced via debtors' prison. Financial debts could be transformed under the pressure of incarceration, and the settlement of accounts taking place in this manner garnered little notice because it was increasingly the lower classes which felt its brunt.

The category of indispensables the household of the debtor retained was based on an increasingly taxonomic form of knowledge. Here, too, the bypassing of a problematic of knowledge became apparent when objects were employed to define the limits of collateral. The federal statute of 1892 extended these limits in a time when the concept of the "minimum" was becoming central in public debate. The indispensable household utensils were used more and more to define a generalized standard. Within this process, the appeal of materiality in liberal legal thought is evident, for this "minimum" was outlined not in monetary terms but rather in material terms. In that sense, it related claims of entitlement to a minimum of things.

The ongoing significance of compartmentalized knowledge, a partial shift from investigative to taxonomic knowledge, a steady unease with liminal relations: viewed together, these knowledge practices reveal new insight into liberal authority. Further, they highlight a facet of force in liberalism that has been seldom addressed. Collateralization via attachment was not a distant, abstract act of state, but rather a concrete, tangible instance in which force was employed to protect that which was perceived to be natural circulation within the credit market. The supposedly free circulation was underpinned by the efforts of an intrusive state. 
Thus the methods of collateralization can be viewed as a double movement: as an untangling of social relationships which nevertheless created new, unpredictable complications. Although collateralization was seen to reduce complexity, new entanglements entered through the back door. Each of the knowledge practices involved in the method of collateralization brought with it certain epistemic concerns: the sale and circulation of mortgages on real estate undermined the distinction of movable and fixed property; the legal attachment of goods failed due to the intertwined modalities of payment in the early phases of industrialization; collateralization aimed to recoup the monetary value of the goods attached, but denied the debtor of a much greater value, namely the value of the goods in their everyday use; in the eyes of its critics, incarceration of debtors did not facilitate rational access to their property, but it did unleash uncontrolled passions; and, finally, the economic conversion intrinsic in pawnbroking seemed to be inextricably tied up with moral quandaries.

This essay set out to show that collateralization sought to transform the relationship which debt created between an object and a person. Furthermore, the process of abstraction as well as the particularization by the method of collateralization transformed the object itself. This allows for a methodological conclusion. Instead of starting with an assumed a priori "intrinsic logic" of things, this essay examined how the angle of perception and the transaction that framed an object interacted; the aim thereby was to locate the source of this "intrinsic logic." It was due to the institutions and processes of mediation rather than mechanical determinism that objects employed as collateral could facilitate stability in the day-to-day economy under liberalism even as this process constantly created new confusion. 